\title{
MAQASHID AS-SYARIAH TERHADAP HUKUM ISLAM MENURUT IMAM AS-SYATIBI DALAM AL-MUWAFAQAT
}

\author{
Nirwan Nazaruddin \& Farhan Kamilullah \\ Dosen STAI Asy-Syukriyyah Tangerang \\ nirwan@asy-syukriyyah.ac.id \& \\ farhan.kamilullah@asy-syukriyyah.ac.id
}

\begin{abstract}
Abstrak
Perkembangan fiqh islami (Islamic Jurisprudence) telah melalui beberapa dekade penting dalam ranah sejarah klasik umat Islam. Sejarah ini terbentang luas mulai dari masa pembentukan (age of foudation) sampai masa kebangkitan atau reformasi (age of remormation). Dalam sejarah klasik ini tergambar jelas elastisitas fiqh dalam menjawab tantangan zaman sebagai implementasi karakter dasarnya yang bersifat zhoniyyat. Adagium yang selalu dielukan fiqh atas Islamic Jurisprudence: sholih li kulli zaman wa makan, semakin menempati posisinya yang jelas dalam ranah pemikiran kontemprer dan semakin menguat semenjak diketemukannya kitab al-Muwafaqot karangan Imam AsSyatibi sebagai konsep dasar metodologi hukum Islam dalam menjawab tantangan sosial yang terus berkembang sejalan dengan kemajuan ilmu pengetahuan dan tekhnologi, sehingga mendahulukan maslahah diatas teks ketika terjadi polemik adalah suatu keniscayaan.
\end{abstract}

Kata kunci : Ushul fiqh, Maqashid asy-syari'ah, As-Syatibi

\section{ملاخصة}

هذه المرحلة .ان تطور الفقه الاسلامي قد تجاوز المرحلة الهامة في تاريخ التراث الاسلامي ويظهر مبدأ التيسير فى حل .بدأت بمرحلة التشريع في علم الفقه حتى مرحلة التقدم باه ان المصطلة التي يذكرها مساءله المتنوعاة، تطبيقا لصفته الاصلية وهي من الظنيات علم الفقاه دائما كالشريعة الاسلامية وهو صالح لكل زمان ومكان ياخذ مكانه بعد ان الف كتاب الموافقات للشاطبي كالاسـاس الميتودولوجي للحكم الاسلامي فى حل مساء ل المجتمع المتغير بجانب تقدم العلوم والتكنولوجي حيث يقدم المصلحة على النص حينما يقع الحوار بينهما 


\section{A. PENDAHULUAN}

Kompleksitas ranah historis manusia dengan berbagi wacana, model, dan aktivitas yang mengitarinya yang setiap hari berubah dan bahkan tampak pelik seakan tidak tertampung dalam nilai/norma hukum yang ada dalam nash (qur'an-sunnah) saat ini. Tatanaha al-nushus wala tatanaha al-waqa'i (wahyu sudah tidak lagi diturunkan, sementara peristiwa/kebutuhan hukum terus berkembang) sehingga mengharuskan para mujtahid (cendikiawan/pakar hukum) untuk dapat melakukan ijtihad dalam rangka pembaharuan (reformasi) terhadap hukum itu sendiri. Sehingga kaidah "alislam sholih likulli zaman wa makan" merupakan sebuah keniscayaan.

Pemikiran fiqih islam secara perspektif ini bertujuan menggali norma-norma Islam dalam tatanan das sollen, yaitu norma-norma yang dipandang ideal untuk dapat mengatur tingkah laku manusia dan menata kehidupan bermasyarakat yang baik. ${ }^{1}$ Menurut istilah Harold. J. Berman ${ }^{2}$ perubahan hukum menunjukan pada pengertian bahwa hukum selalu mengalami pertumbuhannya, hukum berinteraksi dengan sektorsektor kehidupan sosial manusia secara sistematik. ${ }^{3}$

Ibn Qayyim al-Jauziyah, seorang ulama madzhab Hanbali, pernah membuat statemen populer, yakni : "syariat Islam berdiri diatas pondasi kebijaksanaan dan kepentingan hidup ummat manusia didunia dan diakhirat". Secara keseluruhan, syariat Islam bercirikan keadilan, rahman, mashlahah, dan hikmah. Oleh karena itu, setiap masalah yang menyimpang dari sifat keadilan menuju kezaliman, dari rahman menuju adzab, dari maslahah menuju mafsadah, dari hikmah menuju kesia-siaan, maka

\footnotetext{
${ }^{1}$ Yusdani, Fiqih dan Hak Asasi Manusia (Perspektif Dialogis - Preskriptif-Akomodatif), AlMawarid, Jurnal Hukum Islam, Vol. XV No. 1 Februari - Agustus 2014. Yogyakarta, FIAI UII, hlm. 18

${ }^{2}$ Lihat dalam tulisannya Law and Revolution: The Formation of The Western Legal Tradition: The Formation Of Western Legal Tradition, (Cambridge: Harvard University Press), 1983, hlm. 9

${ }^{3}$ Mashudi, Legal Responsibility: Membumikan Asas Hukum Islam di Indonesia, (Yogyakarta: pustaka Pelajar), 2015, hlm. 2
} 


\section{Jurnal Asy-Syukriyyah}

masalah tersebut tidaklah termasuk ke dalam lingkaran syariat Islam walaupun dipaksakan untuk dimasukannya dengan jalan ta'wil. ${ }^{4}$

Syaikh Abdul Wahhab Khallaf menulis," setiap hukuman pasti terbentuk berdasarkan hikmahnya. Adanya hikmah menentukan adanya hukum karena hikmahlah salah satu pendorong disyariatkannya suatu hukum, dan tujuan akhir yang maksud akhi. Akan tetapi setelah dilakukan observasi hikmah disyariatkan sebagai hukum merupakan hal yang samar diketahui. Masih menurut beliau hikmah tidak bisa dijadikan patokan karena tidak kepastiannya tidak bisa menjangkau seluruh aspek karna tekadang hanya sebagian contoh kecil saja. Seperti hikmah orang sakit tidak boleh berpuasa adalah agar terhindar dari penyakit masyqqah. Hal ini tidak bisa dibakukan tidak semua orang sakit parah mampu berpuasa dan merasa perlu hikmah ini. Oleh sebab itu, mujtahid merasa perlu menggali alasan baku (illat) yang bisa mengkomodir seluruh permaslahan "maka prinsip perbedaan hikmah dan alasan baku, hikmah adalah motivasi pendoorong, dan tujuan akhir, yang merupakah maslahat, kenapa suatu hukum perlu disyariatkan, atau kenapa kemafsadahan suatu hukum perlu dihindari sedangkan alasan baku. Adalah patron yang bisa mengkomodir adanya suatu hukum, dimana ia ada dan dimana ia tidak ada. ${ }^{5}$

Izzadun Ibn Abdus Salam (660/1263) tertuang dalam monumentalnya, qaawad il ahkam fii masalih al-anam dia cenderung sufistik tentang hukum dalam konsep pembahasan maslahah. Bagi dia mashlahah adalah kenyaman kegembiraan serta sarana sarana yang membawa kita keduanya. Oleh karena itu, mashalih terbagi menjadi dua jenis; maslahah dunia dan maslahah akhirat. Maslahah dunia dapat diketahui oleh akal sedangkan maslahah akhirat hanya dapat diketahui oleh naql (hadits dan wahyu). ${ }^{6}$

\footnotetext{
${ }^{4}$ Ibnu al-Qoyyim al-Jauziyah, I'lam al-Muwaqqi'in an Rabb 'alamin, Juz III, (Beirut: Darul Kutub al-Ilmiyah, tt) hlm. 11

${ }^{5}$ Lihat Abdul Wahhab Khallaf, Ilmu Ushul Fiqih, (Semarang: Dina Utama, 1994), hlm. 64-65

${ }^{6}$ Ibn Salam, Qawaid al-Ahkam fii Mashalih al-Anam, Maktab Syamilah, Vol. II hlm. 6-10
} 


\section{Jurnal Asy-Syukriyyah}

Maqasid al-Syariah atau tujuan tujuan hukum Islam secara historis merupakan kelanjutan dan perkembangan dari konsep hikmah illah dan maslahah walaupun pengunaaan ketiga istilah ini terhadap penetapan hukum terdapat penentangan dalam kalangan mutakalimin dalam ushuliyyin yang pada akhirnya menimbukan aliran aliran dalam maqasid al-Syariah itu sendiri. Istilah maslahah telah menjadi suatu konsep yang sistematis setelah As-Syatibi melakukan kajian yang mendalam terhadap maslahah sehingga melahirkan konsep maqasid al-Syariah dalam sebuah karya monumental al-muwafaqat-nya.

\section{B. PEMBAHASAN}

\section{Definisi Maqashid Asy-Syariah}

Apabila dilakukan istiqra' tentang tata cara pengguanan bahasa kedalam bahasa arab, dan mengetahui asal-usul kalimat Maqashid Asy-Syari'ah, dapat dikatakan bahwa; maqashid berasal dari fii'l tsulasi - قصد - يقصد - قصدا - مقصدا)

(مقاصدا yaitu bentuk jama' taktsir dari masdar mim, yang berarti "maksudmaksud atau tujuan-tujuan". 7 Sedangkan syari'ah menurut bahasa berasal dari ) ( شريعة شرع - يشرع - شرعا yang berarti aturan atau undang-undang. ${ }^{8}$ Ada pun maqashid as-syari'ah apabila dtinjau dari segi istilah sebagaimana dikatakan oleh al-Zaili adalah segala makna, sasaran atau tujuan hukum yang diperhatikan syara' dalam seluruh atau sebagian besar ketetapan hukum, atau sebagai tujuan akhir syari'at serta rahasia yang ditetapkan syari'ah pada setiap hukum.

Menurut hemat penulis, apabila ingin mengetahui lebih dalam akan definisi maqashid asy-Syari'ah, hal ini tidak dapat terlepas akan awal kemuculan istilah kalimat tersebut. Kemunculan istilah maqashid asy-Syariah secara teknis dicetuskan oleh as-Syatibi dalam al-mufaqatnya namun As-Syatibi sendiri dalam mengomentari maqashid, dia mengindentikan dengan istilah mashalih. Mashalih

\footnotetext{
${ }^{7}$ Yusuf Ibn Abdullah Al-Syabili, Maqashid al-Syari'ah Islami, tp, th, hlm.4

${ }^{8}$ Lihat Al-Munawwir, Kamus Al-Munawwir Arab - Indonesia, Pustaka Progressif, Surabaya,
} hlm. 711 
menurut As-Syatibi adalah perolehan apa-apa yang menyangkut rizki manusia, pemenuhan penghimpunan manusia dan peroleh apa-apa yang dituntut oleh kualitas-kualitas emosional dan intelektualnya, dalam pengertian yang mutlak. ${ }^{9}$

Adapun maslahah menurut al-Ghazali adalah ungkapan untuk mencari sesuatu yang bermanfaat (manfa'ah) atau menghilangkan sesuatu yang merugikan (madharat). Lebih lanjut al-ghazali mengatakan; maslahah adalah memelihara tujuan syari'at atau yang mencakup lima hal : memelihara agama, kehidupan, akal, keturunan dan harta. ${ }^{10}$

\section{Historisitas dan Epistemologi Maqashid Al-Syariah}

Dalam kajian sejarah maqashid al-syariah kita dihadapkan dengan sebuah pertanyaan besar, siapa peletak pertama maqashid al-syariah ? konon katanya, AsSyatibi 'ulama dari mazhab maliki merupakan peletak pertama, atau memang jauh sebelum As-Syatibi istilah maqashid al-Syariah telah dibicarakan. Oleh karena itu, dalam sub bahasan ini penulis mencoba menguraikan akar sejarah istilah maqashid al-Syariah.

Secara formal, istilah maqashid belum dikenal pada awal islam. Namun, pada waktu itu para pakar hukum islam mengenal istilah maslahah. Maslahah, sebagai salah satu prinsip penalaran hukum - secara luas, menyatakan bahwa "kebaikan" adalah "halal" dan bahwa "halal" mestilah baik - akhirnya digunakan dimasa paling awal dari perkembangan fiqih. Penggunaan prinsip ini dinisbatkan, misalnya kepada yuirs-yuris awal dari "mazhab hukum kono" atau bahkan kepada sahabat-sahabat nabi. Diantaranya pendiri mazhab fiqih, dia diasosiasikan kepada malik bin Anas. ${ }^{11}$

Kata al-Maqashid sendiri pertama kali digunakan oleh at-Turmuzi alHakim, ulama yang hidup pada abad ke-3. Dialah yang pertama kali menyuarakan

\footnotetext{
${ }^{9}$ Abu Ishak As-Syatibi , al-Muwafaqat fi Ushul Syari'ah, (Beirut Libanon: Darul Kutub al-
} Ilmiyah) hlm. 25

${ }^{10}$ Al-Ghazali, Mustashfa min ilmi al- Ushul al-Figh, Maktabah syamilah, vol. I hlm. 285

${ }^{11}$ Muhammad Khalid Mas'ud, Filsafat Hukum Islam, (Bandung: Pustaka, 1996) hlm. 160 
maqashid al-Syari'ah melalui buku-bukunya, al-Shalah wal maqashiduhu, al-haj wa Asraruh, al-illah, 'Ila al-Syari'ah, 'Ila al-'ubudiyyah dan juga bukunya alfuruq yang kemudian diadopsi oleh imam al-Qarafi menjadi judul buku karangannya.

Setelah al-hakim kemudian muncul Abu Mansur Al-Maturidy (w. 333) dengan karyanya ma'khad al-Syara ' disusul Abu Bakar al-Qaffal al-Syasyi (w. 365) dengan bukunya ushul al-fiqh dan mahasin al-Syari'ah. Setelah al-Qaffal muncul abu bakar al-abhari (w. 375) dan al-Baqilany (w.403) masing-masing dengan karyanya, diantaranya, Mas'alah Al-Jawab Wa Al-Dalail Wa Al 'Illah Dan Al-Taqrib Wa Al-Irsyad Fi Tartib Thuruq Al-Ijtihad. Sepeninggal alBaqillany muncullah al-haramayn al-Juwaeny (438/1047), dengan analisisnya mengenai maslahah sebagi basis ekstratekstual penalaran dalam konteks qiyas dengan 'illah. Al-Haramayn, dalam al-Burhan, menyatakan ; kesahihan penalaran atas dasar maslahah menjadi perbincangan sehingga melahirkan tiga mazhab pemikiran menyikapi kajian mashlahah. ${ }^{12}$ Setelah itu istilah mashlahah dan mashalih digunakan oleh toko mu'tazilah abu Husain al-Bashri (w. 478/1065). Baginya mashlahah adalah hal-hal baik atau kebaikan. Basri membahas maslahah dengan merujuk kepada 'illah. Disatu tempat ia mendefinisikan al-Mashalih alSyar'iyyah dengan tindakan-tindakan yang wajib berdasarkan syari'at.

Pada abad-abad berikutnya konsep masalih memperoleh kemajuan yang sangat penting. Ada dua tahap utama dalam perkembangan kosep ini. Perkembangan yang pertama ditunjukan oleh al-Ghazali pada abad ke dua belas dalam sebuah karyanya al-mustasyfa, sedangakan kedua oleh al-razi pada abad ke tiga belas dalam al-Mahsul.

Dalam karyanya al-ghazali tersebut, maslahah dibahas lebih lengkap. Ia membagi maslahah menjadi tiga katagori. Pertama, jenis maslahah yang memiliki

\footnotetext{
${ }^{12}$ Muhammad Khalid Mas'ud, Filsafat Hukum Islam, (Bandung: Pustaka, 1996) hlm. 161-162
} 
bukti tekstual (dapat digunakan peng-qiyas-an). Kedua, maslahah yang diingkari oleh bukti tekstual (dilarang peng-qiyas-an). Ketiga, jenis maslahah yang tidak didukung atau disangkal oleh bukti tekstual (maslahah yang memerlukan pertimbanagan). Dari segi ini ada tiga tingkatan maslahah : yaitu daruriyah, hajat dan tahsinat.

Al-Mustashfa al-Ghazali tetap merupakan sumber utama yang mempengaruhi pekembanangan selanjutnya, sampai muncul karya monumental al-razi dengan al-Mashahul-nya. Al-Razi tidak mendefinisikan maslahah, tetapi nampak bahwa dalam pemikirannya manasib dan maslahah saling berkaitan erat. Dia mendefinisikan. Pertama, manasib didefinisikan sebagai "apa yang membawa manusia kepada apa yang baik-baik, dalam " memperoleh" maupun "pelestarian". Sedangkan definisi manasib kedua ialah “apa-apa yang biasanya cocok (fi'l 'adah) dengan perbuatan orang-orang bijaksana. Al-Razi kemudian menjelaskan bahwa definisi yang pertama diterima oleh mereka yang menisbatkan hikmah dan maslahah sebagai sebab-sebab atau motif-motif dari perintah tuhan. Sedangkan definisi yang kedua digunakan oleh mereka yang tidak menerima kuasalitas. Sebagaimana al-ghazali, al-razi-pun membahas maslahah kepada tiga; maslahah dharuri, maslahah haji dan maslahah tahsini. ${ }^{13}$

Sepeninggalan al-Razi ada beberapa karya yang membahas para ahli hukum islam. Karya-karya tersebut dapat terlihat dalam empat kecendrungan. Kencendrungan pertama, merujuk kepada mereka yang kensepsinya tentang maslahah adalah entah secara dominan serupa dengan konsep al-Razi tentang manasib dan maslahah. Dikalagan malikiyah, Syihabudin Al-Qarafi (684/1285), dikalangan hanafiyah, Shadr al-Syari'ah al-Mahbubi (747/1346), Jamaludin AlIsnawi (771/1370) dan tajuddin al-Subki (771/1369) menggabungkan al-ghazali dan al-Razi. Kecendrungan ke-dua, merujuk kepada para yuris yang menolak al-

\footnotetext{
${ }^{13}$ Muhammad Khalid Mas'ud, Filsafat Hukum Islam, (Bandung: Pustaka, 1996) hlm. 168-171
} 
maslahah sebagai dasr penalaran yang sahih, dalam katagori ini masuk mazhab alsyafi'i, Safiudin al-Amidi (631/1234) dan yuris al-Maliki, ibn Hajib (646/1249).

Kecendrungan ketiga, Izzuddin Ibn 'Abdus Salam (660/1263)tentang dalam karya momumentalnya, Qawa'id Al-Ahkam Fii Masalih Al-'Anam. Dia cenderung sufistik tentang hukum dalam konsep pembahasan maslahah. Bagi maslahah adalah kenyamanan, kegembiraan serta sarana-sarana yang membawa kepada keduanya. Karena itu, mashalih terbagai menjadi dua jenis ; mashalih dunia dan mashalih akhirat. Mashalih dunia dapat diketahui oleh akal sedangkan mashalih akhirat hanya dapat diketahui oleh naql (hadis dan wahyu). ${ }^{14}$ Ditempat lain Ibn Abd Salam membagi maslahah menjadi dua bagian utama. Yang pertama adalah hak-hak allah dan kedua adalah hak-hak manusia. Hak-hak tuhan mencakup tiga katagori ; hak-hak yang murni milik tuhan, semisal ma'arif dan ahwal. Kedua yang menggabungkan antara hak-hak tuhan dengan hak-hak manusia, semisal zakat. Ketiga, hak-hak yang menggabungkan hak-hak tuhan dengan hak rasulnya serta hak-hak manusia pada umumnya. Hak-hak manusia juga mencakup tiga katagori; hak-hak sendiri, hak-hak sesama manusia dan hak binatang dan manusia. ${ }^{15}$

Kecendrungan keempat ditampilkan oleh Ibn Taymiyah (728/1328) dan Ibn Qayyim Al-Jauziah (751/1350). Ibn Taymiyah mencoba menemukan jalan tengah "penolakan total dan penerimaan total terhadap maslahah". Ia memandang al-maslahah mursalah sama dengan metode ra'y, istihsan, kasyf (ungkapan mistik) dan dzauwq (cicipan mistik) yang dia curigai kesahihannya, dan karenanya ditolak. Dilain pihak dia menolak implikasi-implikasi moral dari penyangkalan terhadap maslahah dalam perintah-perintah tuhan. Lebih jauh Ibn Taymiyah menyimpulkan bahwa berargumen dengan al-maslahah mursalah berarti membuat hukum dalam agama dan tuhan tidak membolehkan hal itu, melakukan hal itu

\footnotetext{
${ }^{14}$ Ibn Abi Salam, Qowaid al-Ahkam fi Mashalih al-Anam, Maktab Syamilah, vol II 6-10

${ }^{15}$ Ibn Abi Salam, Qowaid al-Ahkam fi Mashalih al-Anam, Maktab Syamilah, vol II, hlm. 24
} 
sama saja melakukan istihsan dan tahsin 'aql. Dia mengakui bahwa syariat tidak bertentangan dengan maslahah, tetapi manakala menemukan dengan akal akan adanya maslahah dalam sebuah kasus tertentu dimana tidak ada nash yang bisa ditemukan untuk mendukungnya, maka hanya ada dua arti. Entah secara pasti ada sebuah tertentu dimana tidak ada nash yang tidak ketahui oleh si pengamat, atau dia tidak sedang berurusan dengan maslahah sama sekali. ${ }^{16}$

Dengan melihat sejarah maqashid al-Syari'ah diatas, dapat diambil suatu pernyataan bahwa sebelum asy-Syatibi, sudah ada dan sudah dikenal hanya saja susunanya belum sistematis sehingga datangnya As-Syatibi dengan al-muwafaqat karya monumentalnya, Maqashid Al-Syari'ah telah tersistemasitiskan. Sebagaimana dalam kajian ilmu usul fiqh, imam al-Syafi'i merupakan peletak sistemtisasi usul fiqh. Namun, bukan berarti usul fiqh belum dibicarakan, hanya saja usul fiqh sebelum Syafi'i belum tersusun dengan sistematis. Oleh karena itu pada kajian selanjutnya penulis merasa perlu mengkaji konsep maqashid AsSyatibi

\section{Maqashid Asy Syari'ah As-Syatibi}

Menurut As-Syatibi , kemaslahatan manusia dapat terelasisasi apabila lima unsur pokok kehidupan mansuia dapat diwujudkan dan dipelihara,yaitu agama, jiwa, akal, keturunan, dan harta. Dalam kerangka ini, ia membagi maqashid menjadi tiga tingkatan, yaitu dharuriyat, hajiyat dan tashiyat.

1) Dharuriyat

Jenis maqhasid ini merupakan kemestian dan landasan dalam menengakan kesejahteraan manusia di dunia dan akhirat yang mencakup pemeliharaan lima unsur pokok dalam kehidupan manusia, ${ }^{17}$ yang mencakup a. Agama (din)

${ }^{16}$ Muhammad Khalid Mas'ud, Filsafat Hukum Islam, (Bandung: Pustaka, 1996) hlm. 177-178

${ }^{17}$ Adiwarman Karim, Sejarah Pemikiran ekonomi Islam, (Jakarta: PT RajaGrafindo Persada, 2004), hlm. 319 

b. Kehidupan (nafs)
c. Pendidikan (aql)
d. Keturunan (nasl), dan
e. Harta (mal) ${ }^{18}$

Pengabdian terhadap kelima unsur pokok tersebut akan menimbulakn kerusakan di muka bumi serta kerugian yang nyata di akhirat kelak. Pemeliharaan terhadap agama, jiwa, akal, keturuanan, dan harta dapat dilakukan dengan cara memelihara eksistensi kelima unsur pokok tersebut dalam kehidupan manusia dan melindunginya dari berbagai hal yang dapat merusak, sebagai contoh, penunaian hukum islam, pelaksanaan kehidupan manusiawi serta larangan mencuri masing masing merupakan salah satu bentuk pemeliharaan eksistensi agama dan jiwa serta perlindungan terhadap eksistensi harta. ${ }^{19}$

2) Hajiyat

Jenjang ini merupakan pelengkap yang megokohkan,menguatkan dan melindungi jenjang dharuriyat. $^{20}$ Jenis maqashid ini dimaksudkan untuk mempermudah kehidupan menghilangkan kesulitan atau menjadikan pemeliharana yang lebih baik terhadap lima unsur pokok kehidupan manusia contoh jenis maqasid ini antara lain mencakup kebolehan untuk melaksanakan akad mudharabah, muasyaqat, muzara'ah dan bai salam, serta berbagai aktivitas ekonomi lainnya yang bertujuan untuk memudakan kehidupan atau menghilangkan kesulitan manusia di dunia. ${ }^{21}$

3) Tahsiniyat

${ }^{18}$ Muhammad Muflih, Perilaku Konsumen dalam Perpektif Ilmu ekonomi Islam, (Jakarta: PT RajaGrafindo Persada, 2006) hlm. 66

${ }^{19}$ Adiwarman Karim, Sejarah Pemikiran ekonomi Islam, (Jakarta: PT RajaGrafindo Persada, 2004), hlm. 320

${ }^{20}$ Muhammad Muflih, Perilaku Konsumen dalam Perpektif Ilmu ekonomi Islam, (Jakarta: PT RajaGrafindo Persada, 2006) hlm. 66

${ }^{21}$ Muhammad Muflih, Perilaku Konsumen dalam Perpektif Ilmu ekonomi Islam, (Jakarta: PT RajaGrafindo Persada, 2006) hlm. 66 


\section{Jurnal Asy-Syukriyyah}

Jenjang ini merupakan penamah bentuk kesenangan dan keindahan dharuriyat dan hajiyat. ${ }^{22}$ Tujuan jenis maqashid yang ektiga adalah agar manusia dapat melakukan yang terbaik untuk menyempurnakan pemeliharaan lima unsur pokok kehidupan manusia. Ia tidak dimaksudkan untuk menghilangkan atau mengurangi berbagai kesulitan tetapi hanya bertindak sebagai pelengkap, penerang dan penghias kehidupan manusia contoh jenis maqashid ini antara lain mencakup kehalusan dalam berbicara dan bertindak serta pengembangan kualitas produksi dan hasil pekerjaan. $^{23}$

Lima kebutuhan dhaririyat (esensial) yang menyangkup din, nafs, aql, nasl, dan mal merupakan satu kesatuan yang tak dapat dipisahkan, manusia hanya dapat melangsungkan hidupnya dengan baik jika kelima macam kebutuhan ini terpenuhi dengan baik pula, ${ }^{24}$ maka orientasi yang dibangun dalam melakukan produksi adalah tidakan yang seharusnya dilakukan oleh setiap pelaku ekonomi muslim dalam mengarahkan kegiatan produksinya untuk memenuhi kebutuhan dara manusia yang lima tersebut. ${ }^{25}$

\section{Peranan Maqashid Syari'ah dalam Pengembangan Hukum}

Pengetahuan tentang maqashid Syari'ah, seperti ditegaskan oleh abd alwahhab Khalif, adalah hal sangat penting dapat dijadikan alat bantu untuk memahami redaksi al-Qur'an dan sunnah, menyelesaikan dalil-dalil yang bertentangan dan yang sangat pentinglagi adalah untuk menetapkan hukum terhadap kasus yang tidak tertampung oleh al-Qur'an dan Sunnah secara kajian kebahasaan. $^{26}$

${ }^{22}$ Adiwarman Karim, Sejarah Pemikiran ekonomi Islam, (Jakarta: PT RajaGrafindo Persada, 2004), hlm. 321

${ }^{23}$ Muhammad Muflih, Perilaku Konsumen dalam Perpektif Ilmu ekonomi Islam, (Jakarta: PT RajaGrafindo Persada, 2006) hlm. 66

${ }^{24}$ Muhammad Muflih, Perilaku Konsumen dalam Perpektif Ilmu ekonomi Islam, (Jakarta: PT RajaGrafindo Persada, 2006) hlm. 66

${ }^{25}$ Eko Prayitno, Ekonomi Mikro Perspektif Islam, (Malang: UIN Malang Press, 2008) hlm 185

${ }^{26}$ Satria Efendi, Ushul Fiqh, (Jakarta: Gramedia, 2004) hlm. 237 
Metode istinbat, seperti qiyas, istihsan, dan maslahah mursalah adalah metode-metode pengembangan hukum Islam yang didasarkan atas maqashid Syari'ah. Qiyas, misalnya, baru bisa dilaksanakan jika dapat ditemukan maqashid Syari'ah-nya yang merupakan alasan logis ('illat) dari suatu hukum. Sebagi contoh, tentang kasus diharamkannya minuman khamar (QS. Al-maidah : 90). Dari hasil penelitian ulama ditemukan bahwa maqashid Syari'ah dari diharamkannya minuman khamar ialah sifat memabukannya yang merusak akal pikiran. Dengan demikian, yang menjadi alasan logis ('iilat) dari keharaman khamar adalah sifat memabukkannya, sedangkan khamar itu sendiri hanyalah sebagai salah satu contoh dari yang memabukkan.

Dari sini dapat dikembangkan dengan metode analogi (qiyas) bahwa setiap yang sifatnya memabukkan adalah juga haram. Dengan demikian, 'iilat hukum dalam suatu ayat atau hadis bila diketahui, maka terhadapnya dapat dilakukan qiyas (analogi). Artinya, qiyas hanya bisa dilakukan jika ada ayat atau hadis yang secara khusus dapat dijadikan tempat mengqiyaskannya yang dikenal dengan Al-Maqis 'alaih (tempat mengqiyaskan).

Jika tidak ada ayat atau hadis secara khusus yang akan dijadikan al-maqis 'alaih, tetapi termasuk dalam tujuan syariat secara umum seperti untuk memelihara sekurangnya salah satu dari kebutuhan-kebutuhan diatas tadi, dalam hal ini dilakukan metode maslahah mursalah. Dalam kajian ushul fiqh, apa yang dianggap maslahat bila sejalan atau tidak dengan petunjuk-petunjuk umum syariat, dapat diakui sebagai landasan hukum yang dikenal maslahat mursalah.

Jika yang akan diketahui hukumnya itu telah ditetapkan hukumnya dalam nash atau melalui qiyas, kemudian karena dalam satu kondisi bila ketentuan itu diterapkan akan berbenturan dengan ketentuan atau kepentingan yang lebih umum dan lebih layak menurut syara' untuk dipertahankan, maka ketentuan itu dapat ditinggalkan, khus dalam kondisi tersebut. Ijitihad seperti ini dikenal dengan istihsan. Metode penetapan hukum melalui maqashid Syari'ah dalam praktik- 
praktik istinbat tersebut, yaitu praktik qiyas, istihsan, dan istislah (malsalahah mursalah), dan lainya seperti istishab, sad al-zari'ah. Dan 'urf (adat kebiasan), disamping disebut sebagai metode penetapan hukum melalui maqashid Syari'ah, juga oleh sebagian besar ulama ushul fiqh disebut sebagai dalil-dalil pendukung, seperti telah diuraikan secara singkat pada pembahasan dalil-dalil hukum diatas.

Setelah meyakinkan bahwa hukum-hukum syariat mengandung hikmah. Maka kemudian Imam syatibi mulai merinci pembahasan Maqashid Syari' sebagai berikut:

a. Maqashid Syari' dalam meletakkan syariat untuk permulaan ( tujuan utama syariat diturunkan )

Dalam pembahasan pertama tentang maqashid syari' ini, Imam Syatibi membaginya kepada 13 masalah ( sub bahasan ). Inti pembahasan dari ketiga belas 13 masalah ini adalah bahwa tujuan diberlakukannya syariat ialah demi keberlangsungan kehidupan di alam raya berserta isinya, yang kemudian bisa dirinci ke dalam 3 bagian:

1) Tingkatan Maqashid berdasarkan kemaslahatan, beserta hubungan tingkatan satu dengan yang lain. ( Macam Maqashid syariat berdasarkan kemaslahatan terbagi tiga, yaitu Dharuriyyat (primer), Hajiyyat (sekunder), Tahsiniyyat (tersier): Hubungan ketiganya saling melengkapi satu dengan yang lain; Syarat-syarat menjadi pelengkap; Daruriyyat sumber asal Hajiyyat dan Tahsiniyyat).

2) Tinjauan Mashalih ( Kemaslahatan ) dan Mafasid (kerusakan) dalam syariat. (kemaslahatan dan kerusakan berdasarkan persepektif syariat dan realita di lapangan; persepektif Dunia; persepektif Akhirat; Syariat bertujuan membangun kemaslahatan dunia dan akhirat; kemaslahatan yang dipertahankan syariat dan kerusakan yang dicegah syariat; kemaslahatan dunia sebagai pijakan kemaslahatan akhirat; bukti-bukti bahwa syariat bertujuan menjaga kemaslahatan Daruriyyat, Hajiyyat, dan 
Tahsiniyyat; kemaslahatan Daruriyyat, Hajiyyat, dan Tahsiniyyat bersifat universal, tidak dapat dibantah oleh permasalahan yang bersipat parsial ).

3) Syariat terjaga sepanjang masa.

b. Maqashid Syari' dalam Meletakkan Syariat untuk Dipahami.

Pembahasan bagian kedua ini terbagi kedalam 5 masalah. Inti pembahasannya ialah bahwa syariat ini diturunkan dalam bahasa arab, dan bersifat ummi, yang kemudian bisa dirinci menjadi 4 bagian:

1) Al-Qur'an berbahasa Arab seluruhnya, tidak ada campuran bahasa 'Ajam ( Asing ) di dalamnya.

2) Penerjemahan dan penafsiran al-Qur'an ke dalam bahasa asing.

3) Syariat bersifat ummi, karena diturunkan kepada Nabi dan penduduk yang mayoritas ummi. (Artinya syariat turun dengan kemudahan untuk dipahami)

4) Cara menggali hukum syariat berdasarkan Nash-nash syariat, (apakah melalui pemahaman tersurat atau tersirat, atau kedua-duanya )

c. Maqashid Syari' mengenai tatacara manusia masuk kedalam koridor syariat dan bagaimana mengamalkan syariat tersebut.

Pembahasan bagian ini terbagi kedalam 12 masalah. Dengan inti kajiannya bahwa hukum syariat dibebankan kepada mereka yang mampu melaksanakannya. Yang kemudian dapat dirinci kedalam 3 bagian:

1) Qudrah ( kemampuan ) seorang hambah adalah syarat diberlakunnya bembebanan hukum kepadanya.

2) Masyaqqah ( Kesusahan ) dalam pelaksanan hukum syariat. ( Pengertian Masyaqqah; Masyaqqah yang dianggap dan tidak dianggap oleh syariat; Masyaqqah melawan hawa nafsu; Tingkatan Masyaqqah berbeda-beda )

3) Wasathiyyah ( tidak berlebihan-lebihan ) dalam syariat islam.

d. Maqashid Syari' jika manusia sudah berada koridor syariat. 
Pembahasan bagian terakhir dari Maqashid Syari' ini terbagi kedalam 20 masalah. Inti pembahasannya adalah bahwa tujuan syariat diturunkan adalah untuk mengeluarkan manusia dari kongkongan hawa nafsunya, sehingga ia ikhlas dalam menjalakan titah Tuhannya, tanpa merasa terpaksa.

\section{KESIMPULAN}

Dalam pandangan asy-Syatibi, bahwa jika diteliti seluruh hukum dalam syari'ah, maka semuanya itu dibuat untuk tujuan yang satu, yaitu kemaslahatan manusia (mashalih al-ibah). Atas dasar inilah, As-Syatibi dikenal sebagai salah satu tonggak penting dalam sejarah hukum islam, sebab dialah salah satu ulama yang paling menekankan pentingnya "kemaslahatan" sebagai dasar pemahaman atas hukum Islam.

Menurut asy-Syatibi, maslahat itu bertingkat-tingkat atau hirarkis. Ada 3 (tiga) tingkatan kemaslahatan : (maslahat penyempuran/aksesoris). Maslahat tingkat kedua tentu tidak sepenting maslahat tingkat pertama, dan maslahat tingkat ketiga tentu tidak sepenting maslahat tingkat kedua.

Menurut As-Syatibi , maslahat paling dasar dalam agama ada lima : menjaga agama, menjaga nyawa, menjaga keturunan, menjaga hal milik, dan menjaga akal. Yang apabila dikembangkan penafsirannya, eklima maslahat itu akan berbunyi sebagai berkut: 1) Melindungi kebebasan beragama, 2). Melindungi kelangusan hidup, 3). Melindungi kelangsungan keturunan, 4). Melindungi hak milik, dan 5). Melindungi kebebasan berpikir.

Jika kita tafsirkan dalam bahasa kontemporer, maka kelima maslahat itu akan mencakup perlindungan atas sekurang-kurangnya 3 hak : hak-hak sipil, hak-hak ekonomi, dan hak-hak budaya. 


\section{DAFTAR PUSTAKA}

As-Syatibi , Abu Ishaq, al-Muwafaqat fi ushul al-Syari'ah, Beirut: Darul Ma'rifah,1997.

Raisuni, Ahmad, Nazhriyyah al-Maqashid 'Inda al-Imam Asy-Syatibi, Dar al-AmnRabat, Cet: 3, Thn: 1430 H/2009 M.

As-Syatibi , Abu Ishaq, Al Muawafaqat, editor syekh Abdullah Diraj, Cairo: Dar Al Hadist,2006

Raisuni, Ahmad, Muhadharat Fi al-Maqashid asy-Syariah, Mesir: Dar as-Salam, Cet: 1, $1430 \mathrm{H} / 2009 \mathrm{M}$.

Jughaim, Nu'man, Hazm, Ibn, Taisir al-Muwafaqat Li al-Imam asy-Syatibi, Lebanon, Cet: 1, 2009.

Al-Jaizany, Muhammad Bin Husen, Tahdzib al-Muwafaqat, Sausi Arabia: Dar Ibn alJauzy, $1421 \mathrm{H} / 2009 \mathrm{M}$.

Al-Qur'an dan Terjemahnya, Departemen Agama RI, Jakarta.

Khallaf, Abdul Wahhab, Ilmu Ushul Fiqh, alih bahasa : Moh. Zuhri dan Ahmad Karib, Dina Utama, Semarang, 1994.

Koto, Alaiddin, Ilmu Fiqh dan Ushul Fiqh, Jakarta: Rajawali Press, 2006.

Haroen, Nasrun, Ushul Fiqh, Jakarta: Logos Wacana Ilmu, 1997.

Effendi, satria, Ushul Figh, Jakarta: Prenada Media, 2005.

Junaidi, Abdul Basith, dkk., Islam Dalam Berbagai Pembacaan Komtemporer, Yogyakarta: Pustaka Pelajar, 2009.

Raysuni, Ahmad, Nadhariyyat al-Maqashid 'inda al-Imam asy-Syatibiy, Beirut: alMuassasah al-Jami'iyyah Li ad-Dirasat wa an-Nasyr wa at-Tauzi, 1992.

Abdullah, Amin, dkk. Mazhab Jogja, Menggagas Paradigma Ushul Fiqh Kontemporer, Yogyakarta: Ar-Ruzz Press, 2002. 


\section{Jurnal Asy-Syukriyyah}

Bakri, Asafri Jaya, Konsep Maqashid Syari'ah Menurut As-Syatibi, Jakarta: Grafindo, 1998.

Asmuni, "Studi Pemikiran al-Maqashid (Upaya Menemukan fondasi Ijtihad Akademik Yang Dinamis) “. Al- Mawarid, Jurnal hukum Islam, Edisi XIV. Yogyakarta: FIAI UII, 2005.

Asmuni, dkk. Pribumisasi Hukum Islam ( Pembacaan Kontemporer Hukum Islam Di Indonesia ). Yogyakarta: PPS FIAI UII, 2012.

Al-Ubaydi, Hammadi, Asy-Syatibiy wa Maqashid asy-Syari'ah, Mansyurat Kulliyat adDa’wah al-Islamiyyah wa Lajnah al-Huffadz ‘ ala at-Turas al-Islami, 1992.

Harold J Berman, Law And Revolution: The Formation Of The Western Legal Tradition: The Formation Of The Western Legal Tradition, Cambridge: Harvad University Press, 1983.

' Abd. Salam, Izz ad-Din ibn, Qawa'id al-Ahkam fi Mashalih al-Anam, Beirut: Dar alJayl, 1980.

Auda, Jasser, Maqashid al-Shariah as Philosophy of Islamic Law: A Systems Approach, London: The International Institut of Islamic Thougth, 2007.

Auda, Jassr,, Maqashid Syari'ah Untuk Pemula ( terj. Ali Abd El-Mun’im), (t.t)

Usman, Rekontruksi Teori Hukum Islam ( Membaca Ulang Reaktualisasi Hukum Islam Munawwir Sjadzali), Yogyakarta: eLKiS). 2015.

Masud, Muhammad Khalid, Filsafat Hukum Islam: Studi tentang Hidup dan Pemikiran As-Syatibi , ( Bandung: Penerbit Pustaka cet. Ke-1,1996.

Karim, Adiwarman, Sejarah Pemikiran Ekonomi Islam, Jakarta: PT Raja Grafindo Persada, 2004.

As-Syatibi , Abu Ishaq, al-Muwafaqat fi ushul al-Syariah, kairo: Musthafa Muhammad, Jilid 2, ( t.th ).

Al-Qaradhawi, Yusuf, Fiqih Praktis Bagi Kehidupan Modern, kairo: Makabah Wabah, 1999.

Wael b Hallaq, Sejarah Teori Hukum Islam, Jakarta: Grafindo, 2000.

Effendi, Satria, M.Zein, Ushul fiqh, Jakarta : Gramedia,2004. 


\section{Jurnal Asy-Syukriyyah}

S. Praja, Juhaya, Ilmu Ushul Fiqih, Bandung: Pustaka Setia, 2007.

Al-Mursi, Ahmad, Husain Jauhar, Maqashid Syariah, Jakarta: Amzah, 2009.

Syarifudin, Amir, Usul Fiqh,: Jakarta: Logos wancana Ilmu, 2005,

Al-Ghazali, Mustashfa min 'ilmi al-Usul al-Fiqh, Maktabah Syamilah Vol II

Az-Zarkasyi, al-Bahr al-Muhitin, Maktabah Syamilah Vol II, Jilid VI

Al-Qarafi, Syarh Tanqih al-Fushul, Maktabah Syamilah Vol II

Abi Salam, Ibn, Qawaid al-ahkam fi mashalih al-anam, Maktab Syamilah Vol II 